\section{Magnolia zenii Cheng. 'Pink Parchment'}

\author{
Michael A. Dirr ${ }^{1}$, Jeffrey A. Adkins ${ }^{2}$, and Richard T. Olsen ${ }^{2}$ \\ Department of Horticulture, The University of Georgia, Athens, GA30602-7273
}

Additional index words. deciduous, Magnoliaceae, ornamentals, heat tolerance

Magnolia zenii was first collected in flower on 31 Mar. 1933 by W.C. Cheng on Mt. Boahua (Paohua), Jiangsu Province, China, at 260 to $305 \mathrm{~m}$ (Del Tredici and Spongberg, 1989). The Arnold Arboretum's plant (accession 1545-80-B) was grown from seeds collected in Oct. 1980 from the only known wild population of M. zenii (Del Tredici and Spongberg, 1989). The plant flowered at 7 years of age, was $3.5 \mathrm{~m}$ high, and was the first deciduous magnolia to flower (late March) at the Arnold Arboretum (Del Tredici and Spongberg, 1989). The introduction, history, and taxonomy of $M$. zenii are described by Callaway (1994), Del Tredici and Spongberg (1989), Dirr (1998), Dudley (1983), Gardiner (2000), and Treseder (1978).

\section{Origin}

Seeds of many woody species were collected near the conclusion of the senior author's sabbatical at the Arnold Arboretum, Jamaica Plain, Mass., in Sept. 1991, including 10 Magnolia taxa. Magnolia zenii was the most prominent. Seeds were processed in early September, cleaned, float-tested, and stratified in moist sphagnum peat at $5{ }^{\circ} \mathrm{C}$ for $90 \mathrm{~d}$. Germination percentages were not recorded, but were high for all taxa. Ten seedlings were randomly selected from each taxon and planted at the Univ. of Georgia's horticultural farm on 22 Apr. 1993. Plants were spaced $1.5 \mathrm{~m}$ within rows and $3.6 \mathrm{~m}$ between rows, fertilized with $10 \mathrm{~N}-4.4 \mathrm{P}-8.3 \mathrm{~K}$ at transplant and in March of each subsequent year. Most seedlings flowered within 3 to 5 years. Seedlings of the various taxa were rogued if their flowers, foliage, or habit proved inferior.

After eight growing seasons, only one plant of $M$. zenii remained (Fig. 1). It first flowered in early Feb. 1997 when 3 m high with abundant, large, sweetly fragrant flowers, $50 \%$ larger than the species' average, and constitute the legitimacy of this clone for cultivar status. Tepals were purplish-pink on the backs and white inside. This seedling grew $5.5 \mathrm{~m}$ high and $2.7 \mathrm{~m}$ wide in 8 years with a tight conicalpyramidal outline. This seedling appeared remarkably heat and drought tolerant and received no supplemental water. Georgia experienced some of the driest weather on record with 86,97 , and $117 \mathrm{~cm}$ of rainfall in 2000 ,

Received for publication 2 Apr. 2001. Accepted for publication 31 July 2001.

${ }^{1}$ Professor.

${ }^{2}$ Graduate Research Assistant.
1999, and 1998, respectively, recorded at the horticultural farm, Watkinsville, Oconee County, Ga. (GAEMN, 2001; http://www. griffin.peachnet.edu/bae). Average annual rainfall for this site from 1960 to 1990 was 130 $\mathrm{cm}$.

The above attributes coupled with early flowering (early Feb. 1997, mid-Feb. 1998, late Feb. 2000, and mid-Feb. 2001) contribute to its garden use and potential for breeding. Callaway (1994) reported that no cultivars were selected nor were hybrids made with this species.

\section{Description}

The habit of M. zenii 'Pink Parchment' is conical-pyramidal, secondary branches upswept and borne at 20 to $30^{\circ}$ angles to leader (Fig. 1A). The main trunk is smooth and gray (RHS grey-brown 199D) (Royal Horticultural Society, 1966).

Stems are terete, $\approx 0.3 \mathrm{~cm}$ diameter below the end bud, glabrous, green (RHS yellowgreen 144A) to purple-brown (RHS brown 200A), grayish (RHS greyed-white 156B),

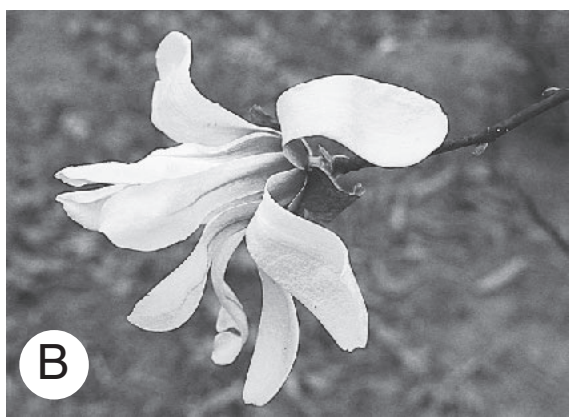
rich purplish-pink coloration. See front cover of this issue. with vertically oriented lenticels, $\approx 0.08 \mathrm{~cm}$ long, \pm 10 per $2.5 \mathrm{~cm}$ of stem length; pith white (RHS white 155D), excavated, greater than one-half the diameter of the stem; leaf scar $0.16 \mathrm{~cm}$ high, $0.48 \mathrm{~cm}$ wide with multiple vascular bundle traces, attached at its ends to the stipular scar that encircles the stem; stem with a strong lemon-safrole odor when bruised. Second-year and older stems become graybrown (RHS greyed-orange 165A).

Flower buds are ovoid-conical, pubescent, covered by a single grayish (RHS greyedgreen 197C) hairy scale, borne at terminal of long shoots and short shoots, 1.3 to $1.9 \mathrm{~cm}$ long. Vegetative buds are elliptical, covered by a single grayish (RHS greyed-green 197C) hairy scale, appressed or slightly divergent from the stem, 0.6 to $1.3 \mathrm{~cm}$ long.

Leaves are alternate, simple, oblong to oblong-ovate, 6.4 to $15 \mathrm{~cm}$ long, 3.8 to $7.6 \mathrm{~cm}$ wide, abruptly acuminate, cuneate to rounded, entire, undulating surface, dark green (RHS green 135B) above, lighter beneath (RHS green 143A), with 10 to 12 lateral veins on either side of the midrib, villous below, petiole 0.6 to $1.9 \mathrm{~cm}$ long, green (RHS green 135B). Leaves are arching in disposition, with the upper surface squarely in the viewer's purview. No fall color develops, as leaves die off green.

Flowers are $\approx 50 \%$ larger than the species' average (Fig. $1 \mathrm{~B}$ and $\mathrm{C}$ ). Each flower is composed of nine tepals, occasionally 10 to 11. Tepals are narrow spathulate, $8.9 \mathrm{~cm}$ long, $2.8 \mathrm{~cm}$ wide $(\mathrm{n}=20)$. Color is purplish-pink (RHS red-purple 64B) in bud, opening white (RHS white 155D) on the adaxial side, the abaxial side of each tepal white (RHS white $155 \mathrm{D})$ at the tip, grading to deep purplish-pink
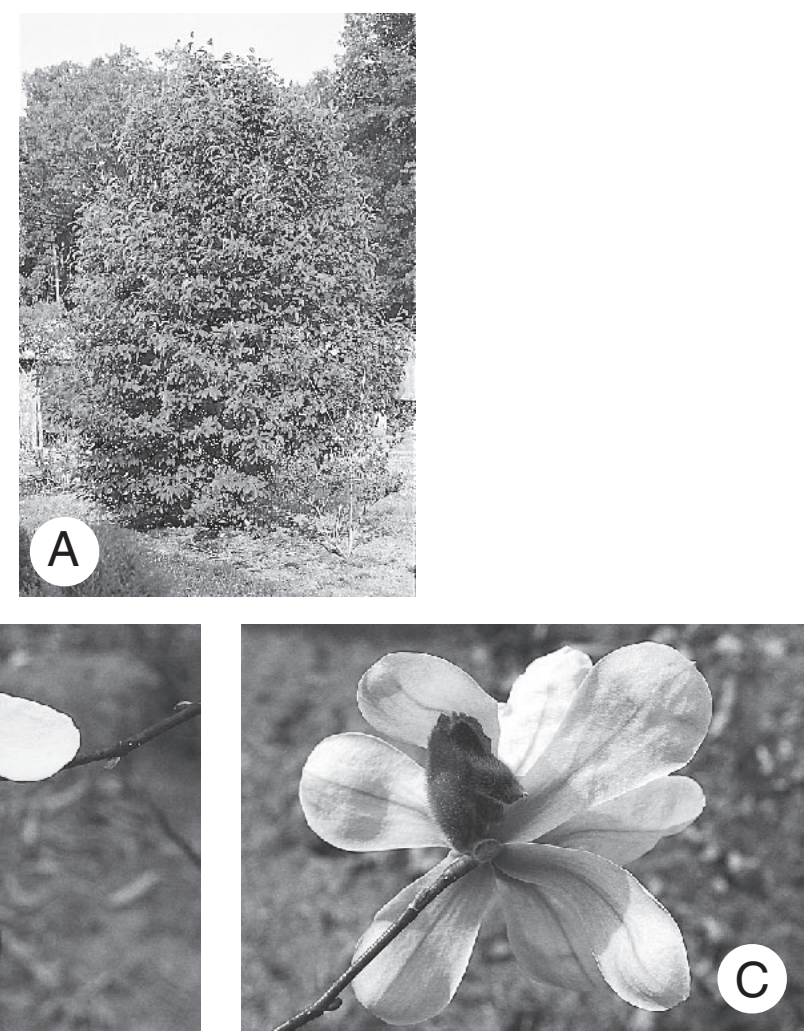

Fig. 1. Magnolia zenii 'Pink Parchment' in (A) habit, (B) open flower, (C) abaxial side of tepals showing 
(RHS red-purple 64B) at the base. A narrow pink (RHS red-purple 73B) central stripe runs from below the tip, becoming purplish-pink (RHS red-purple 64B) and flaring to a triangular shape at the base. Flowers, $15 \mathrm{~cm}$ across when fully open, arch at the middle of the tepals. Fragrance is extremely sweet, more so than $M . \times$ soulangiana Soul.-Bod., M. $\times$ loebneri Kache, and M. stellata (Sieb. and Zucc.) Maxim. taxa. The gynandrophore (where carpels and anthers attach) at anthesis holds a brushy mass of 55 to 60 stamens, each 0.6 to $1.0 \mathrm{~cm}$ long, $0.16 \mathrm{~cm}$ wide. The stamens are purplish-pink (RHS red-purple 64B) on the outside, cream-colored (RHS white 155A) inside with a narrow purplish-pink (RHS redpurple 64B) line down the center. The female portion (aggregate of 50 to 70 follicles) is purplish-pink (RHS red-purple 64A), $1.3 \mathrm{~cm}$ long, $0.48 \mathrm{~cm}$ wide.

Fruits were not observed on this cultivar; however, fruits on the species are 5 to $7.5 \mathrm{~cm}$ long, 1.3 to $2.5 \mathrm{~cm}$ wide, cylindrical aggregates of follicles. Seldom do all follicles contain mature seeds, and the infructescence appears deformed. The seeds are covered with scarlet (RHS red 42A) arils. Fruits of the species ripened in September in Jamaica Plain, Mass. Callaway (1994) listed fruit maturation in June to July.

Based on the initial propagation work with the species, sound seed, stratified in moist peat at $5{ }^{\circ} \mathrm{C}$ for 3 months, germinated in high percentages. Firm-wood cuttings, stems still green, collected 11 Apr. 1997 (Athens, Ga.), untreated or treated with $10,000 \mathrm{mg} \cdot \mathrm{L}^{-1}$ potassium salt of indole-3-butyric acid, 5-s dip, placed in 3 perlite : 1 peat (by volume) medium under intermittent mist rooted $0 \%$ and $75 \%$, respectively, when evaluated 19 June 1997. Del Tredici and Spongberg (1989) reported $80 \%$ germination of seed after 3 months of cold stratification. Cuttings of juvenile $M$. zenii taken between 15 and 30 June (Jamaica Plain) over a 6-year period averaged $80 \%$ when treated with $5000 \mathrm{mg} \cdot \mathrm{L}^{-1}$ indolebutyric acid dissolved in $50 \%$ ethanol.

'Pink Parchment' has reproduced true-totype from cuttings and is amenable to container production. Hardiness is ill-defined, with Griffiths (1992) listing Zone 9 adaptability. The authors' observations and records reflect Zone 6 to 8 adaptability, while Callaway (1994) and Gardiner (2000) surmise Zone 5.

This is the first cultivar of $M$. zenii to be introduced. The early flowers, although frost sensitive, are harbingers of spring. The large, showy, fragrant flowers and uniform growth habit contribute to the garden worthiness and hybridization potential. Although described as a 4.8- to 7-m-high tree in its native China (Callaway, 1994), another seedling (86-0160) in the University's Botanical Garden is now 9 $\mathrm{m}$ high and $6.4 \mathrm{~m}$ wide. However, flowers of $86-0160$ are small, each tepal $5.6 \mathrm{~cm} \times 1.8 \mathrm{~cm}$ $(n=20)$, and open 10 to $14 \mathrm{~d}$ ahead of 'Pink Parchment'.

A voucher specimen (Dirr 103) is deposited in the Univ. of Georgia Botany Dept.'s herbarium (GA). Scientists and breeders interested in scions for grafting or plants should contact the senior author.

\section{Literature Cited}

Callaway, D.J. 1994. The world of magnolias. Timber Press, Portland, Ore.

Del Tredici, P. and S.A. Spongberg. 1989. A new magnolia blooms in Boston. Arnoldia 49(2):2527.

Dirr, M.A. 1998. Manual of woody landscape plants. Stipes, Champaign, Ill.

Dudley, T.R. 1983. Magnolia zenii: A rare magnolia recently introduced into cultivation. Magnolia 19(1):20-22.

Gardiner, J. 2000. Magnolias: A gardener's guide. Timber Press, Portland, Ore.

Griffiths, M. (ed.). 1992. The new Royal Horticultural Society dictionary of gardening. Vol. 3. Macmillan, London.

Royal Horticultural Society. 1966. The Royal Horticultural Society colour chart. Royal Hort. Soc., London.

Treseder, N.G. 1978. Magnolias. Faber and Faber, London. 